\title{
Hugh MacDiarmid: The Impossible Persona
}

David Goldie

One of the most consistent themes in MacDiarmid criticism, dating back almost to its beginning is that of the misunderstanding and disregard to which MacDiarmid and his writing have been subjected. The adjective 'neglected', whether implied or explicitly stated, has been a frequent presence in critical discussion of his work, often being employed as the condition for a necessary reassessment or rehabilitation. ${ }^{1}$ This dialectic of neglect and vindication is one that MacDiarmid himself did much to promote almost from the start of his career and sprang largely from his sense of injustice at being denied his proper place by a combination of English metropolitan prejudice and the small-mindedness of the Scottish cultural and public spheres.

MacDiarmid was and is widely perceived to be a 'difficult' writer, and this may go some way to explaining his agonistic relationship both with his contemporaries and posterity. His difficulty is manifested in a number of ways. Firstly, it is the formal difficulty of an experimental Modernist who challenges the norms of poetic diction and structure. Then it is the difficulty of a writer engaged in a bold attempt to construct a new Scots literary language, one who is, moreover, not afraid to outrage conventional opinion, whether in politics (Three Hymns to Lenin, for example) or sexuality ('Tarras', 'Harry Semen'). And then there is the difficulty of his

\footnotetext{
${ }^{1}$ See, for example, Duncan Glen, ed. Hugh MacDiarmid: A Critical Survey (Edinburgh: Scottish Academic Press,1972), vii. Nancy Gish, Hugh MacDiarmid: The Man and His Work (London and Basingstoke: Macmillan, 1984), 14. Alan Riach, Hugh MacDiarmid's Epic Poetry (Edinburgh: Edinburgh University Press, 1991), x.
} 
compositional practice - his habit of making poems and essays by stringing together fragments drawn opportunistically, and often without attribution, from dictionaries, poems, critical essays, and novels. ${ }^{2}$ Above all, perhaps, sits the problem of MacDiarmid himself: that is to say, the difficulty a reader faces in engaging sympathetically with a persona which at times appears to have been constructed wilfully out of paradox for the purposes of confrontation and provocation; a persona designed less as a consoling, authoritative individuality and more as a catalysing reagent for the generation of a poetry that can be by turns beautiful and cumbersome and opinions that are incisive, awkward, heterodox, and frequently self-contradictory. This is a figure, after all, who could variously call for a Scottish form of Fascism and then renew his support Soviet Communism after the suppression of the 1956 Hungarian uprising; who would famously deride fellow Scottish writer Alexander Trocchi as 'cosmopolitan scum'; who would denigrate traditional Scottish folk poetry as 'songs which reflect the educational limitations, the narrow lives, the poor literary abilities, of a peasantry we have happily outgrown'; and talk openly of 'the moronic character of most of our people' ${ }^{3}$ It is to this difficult and complex persona, 'Hugh

${ }^{2}$ See, among many others, Kenneth Buthlay, 'Adventuring in Dictionaries,' in Hugh MacDiarmid: Man and Poet, ed. Nancy Gish (Edinburgh: Edinburgh University Press, 1992), and Michael H Whitworth, 'Forms of Culture in Hugh MacDiarmid's "Etika Preobrazhennavo Erosa",' International Journal of Scottish Literature 1, no. 5 (2009), http://www.ijsl.stir.ac.uk/issue5/whitworth.htm.

3 'Plea for a Scottish Fascism', Hugh MacDiarmid, The Raucle Tongue: Hitherto Uncollected Prose, ed. Angus Calder, Glen Murray, and Alan Riach, 3 vols., vol. 1 (Manchester: Carcanet, 1996), 82-7. 'Programme for a Scottish Fascism', Hugh 
MacDiarmid', as it is variously manifested in the poetry and, particularly, explicated in the critical and autobiographical books, Scottish Eccentrics (1936) and Lucky Poet (1943), that this chapter is addressed.

Hugh MacDiarmid came into being in 1922: the year, as is often noted, in which James Joyce's Ulysses was first published in book form, in which T. S. Eliot's The Waste Land first appeared, and which saw the first publication of Virginia Woolf's first novel in her mature modernist style, Jacob's Room. When C. M. Grieve invented this new persona he was a thirty-year old writer with a small but growing reputation for accomplished minor verse in English and a strongly-expressed aversion to the tentative current attempts to revive vernacular poetry in Scotland. ${ }^{4}$ He would later claim that his 'earliest literary efforts were all in Scots', but this appears to have

MacDiarmid, Selected Prose, ed. Alan Riach (Manchester: Carcanet, 1992), 34-8. See also Alan Bold, MacDiarmid: Christopher Murray Grieve, a Critical Biography (London: Paladin, 1990), 409-11; Allan Campbell and Tim Niel, eds., A Life in Pieces: Reflections on Alexander Trocchi (Edinburgh: Rebel Inc.,1997), 151; 'Letter to the Scotsman', 13 March 1964, Alan Bold, ed. The Letters of Hugh MacDiarmid (London: Hamish Hamilton, 1984), 821; 'Author's Note 1972', Hugh MacDiarmid, Lucky Poet: A Self-Study in Literature and Political Ideas. Being the Autobiography of Hugh MacDiarmid (Christopher Murray Grieve) (Manchester: Carcanet, 1994), viii.

${ }^{4}$ See, for example, his letter to the Aberdeen Free Press, 30 January 1922, in Bold, ed. The Letters of Hugh MacDiarmid, 754-6. 
no evidential backing and has as a consequence gained little credence among critics. ${ }^{5}$ The switch to Scots dialect with the publication of 'The Watergaw', and to an unambiguously Scottish persona - the dropping of a surname, Grieve, that was of English origin and which spoke of the debatable land of the English-Scottish border, for another, MacDiarmid, that conjured a more straightforward Celtic-highland glamour - changed things irrevocably. In particular, it allowed Grieve the freedom to reinvent himself as someone whose purposes were no longer aligned with the metropolitan literary culture into which he had lately been trying to break through; an individual who now boldly rejected many of the values in which British literary culture was centred. In decentring himself in this way - literally rendering himself eccentric to the dominant culture - MacDiarmid allowed himself not only an enabling freedom from literary, cultural, and political constraint but also the possibility of eventually recentring his political and cultural practice in a reconstituted sense of Scottishness. The manifest oddness and apparent self-contradiction of Hugh MacDiarmid, then, might be said to be, in the first instance, a kind of strategic eccentricity deliberately designed to outrage conventional opinion; an eccentricity designed in particular to discompose and dislocate British literature with a view to the recomposition and relocation of a new independent literature north of the border. In order to do this fully MacDiarmid found it necessary to be not just a 'difficult' character but an 'impossible' one. This, at least, is what he told Neil M. Gunn in 1933

\footnotetext{
${ }^{5}$ MacDiarmid, Lucky Poet, 17. See Kenneth Buthlay, 'Hugh MacDiarmid's “Conversion” to Scots: Practice before Theory,' in Nationalism in Literature Literarischer Nationalismus: Literature, Language and National Identity, ed. Horst W. Drescher and Hermann Volkel (Frankfurt am Main: Peter Lang, 1989), 189.
} 
when he wrote that 'if I am not already literally an impossible person, I intend to become one'. ${ }^{6}$

This sense of strategic eccentricity can be found running throughout much of the work of MacDiarmid's first decade. It can be seen in the formal and thematic structure of A Drunk Man Looks at the Thistle (1926) which destabilises the authority of its speaker by having him fuddled with drink, and disorients its frame of reference with its rapid alternations between low vernacular speculation and high philosophical and literary allusion. It is a wilfully unstable poem that uses its formal and linguistic innovations as a way of estranging its religious and nationalist arguments, prompting the conventional reader to thought by jolting his or her expectations. It is the poem, too, in which MacDiarmid outlines his position of principled self-contradiction, having his speaker commit himself, in a phrase that would come to define MacDiarmid, to 'aye be whaur / Extremes meet'.

This sense of a powerful internal contradiction had preceded the persona of MacDiarmid, having been seen in Grieve's earlier work. In his mid-twenties Grieve had written to George Ogilivie describing 'the many contrasting personalities in me', admitting that 'my thoughts are thus forever like a man moving through the everincreasing and various confusion of an enormous higgledy-piggledy lumber room'. 8

\footnotetext{
${ }^{6}$ Letter to Neil M. Gunn, 22 June 1933, Bold, ed. The Letters of Hugh MacDiarmid,
} 252.

${ }^{7}$ See, for example, Catherine Kerrigan, Whaur Extremes Meet: The Poetry of Hugh MacDiarmid 1920-1934 (Edinburgh: James Thin / Mercat Press, 1983).

${ }^{8}$ Letter to George Ogilivie, 20 August 1916, Bold, ed. The Letters of Hugh MacDiarmid, 10-11. 
His early writing attests to that multiplicity and want of singular focus, as can be seen in the formal and thematic diversity of his first collection Annals of the Five Senses (1923). The opening prose fragment in that collection, 'Cerebral', is often taken as a thinly-veiled autobiographical portrait, and is notable for the way its speaker epitomises the struggles an aspiring artist and thinker has with the contradictions of his own personality: 'he would watch with painful realism the break-up of his mental life. Every one of his separate egos became violently anarchical, creating an unthinkable Babel. Disunity and internecine hostility tore him to shreds. 9

As Hugh MacDiarmid, Grieve was able to find a persona through which that 'unthinkable Babel' might be purposively articulated, and in which he might find an productive outward expression for what had previously been a self-destructive and inward-looking 'internecine hostility'. This is the quality of productive contradiction that critics as diverse as David Daiches and Christopher Whyte have admired in MacDiarmid. Daiches reads a 'Whitmanesque largeness' in MacDiarmid as a consequence of his willingness to embrace his extremes, arguing that 'selfcontradiction is for him a mode of poetic awareness. ${ }^{, 10}$ Whyte suggests that in a work such as the 'entertaining and enormously playful' In Memoriam James Joyce MacDiarmid offers a fundamental challenge to 'the notion of writing as expressing a subjectivity, a pre-existent body of experience or emotions'. For Whyte

\footnotetext{
${ }^{9}$ Hugh MacDiarmid, Annals of the Five Senses: And Other Stories, Sketches and Plays, ed. Roderick Watson and Alan Riach (Manchester: Carcanet, 1999), 13.

${ }^{10}$ David Daiches, 'Hugh MacDiarmid and the Scottish Literary Tradition,' in The Age of MacDiarmid: Essays on Hugh MacDiarmid and His Influence on Contemporary Scotland, ed. P. H. Scott and A. C. Davis (Edinburgh: Mainstream, 1980), 60.
} 
MacDiarmid's playful deconstruction of his own internal coherence as author destabilises readings that are 'underpinned by a coherent psychological reality, associated with the biographical figure', with the result that 'concepts such as originality, subjectivity and intellectual property collapse in the maelstrom of MacDiarmid's compilation'. ${ }^{11}$

This sense of a productive eccentricity, a willed refusal to revolve in a regularly-ordered manner around a stable centre, was immediately apparent in practice in MacDiarmid's various interventions in Scottish culture and politics. In theoretical terms, one of its more forceful and sustained expressions can be found in Scottish Eccentrics. This book offers what would appear to be an appropriately random collection of essays on notable as well as less noted Scottish eccentrics, from the religious enthusiast Elspeth Buchan to the Ossian fabricator James Macpherson, from Lord Monboddo to William McGonagall. In one way the book is a straightforward defence of eccentricity, a plea for the importance of valuing individuals who choose to dance to a different tune. One such is Sir Thomas Urquhart, a Royalist in the civil war period out of step with his time and incapable of being understood by his enemies, "since "only a mind like his own could trace the maze of its windings and turnings, and fathom the depths of its eccentricity. In his thoughts 'truth is constantly becoming interfused with fiction, possibility with certainty, and

\footnotetext{
${ }^{11}$ Christopher Whyte, Modern Scottish Poetry (Edinburgh: Edinburgh University Press, 2004), 93-4.
} 
the hyperbolical extravagance of his style only keeps even pace with the prolific shootings of his imagination'.," 12

Some readers might note a certain similarity between this description and MacDiarmid's own persona, a resemblance that perhaps intensifies as MacDiarmid continues in his description of a figure who 'reminds us of Don Quixote', who makes 'frequent allusions to struggles with pecuniary difficulties, as well as his magniloquent language', and who has a 'lively fancy, a strain of genuine erudition beneath his pedantry, and some sparks of insanity' in his 'fantastical character'. Whether or not there is a degree of self-justification going on here and in the book's other essays, MacDiarmid is clearly making a bold argument about the need to understand rather than simply condemn what appears to the conventional mind to be irrationality and self-contradiction. He is, in this way, not being simply capricious but is following in the footsteps of irrationalist philosophers such as Leo Shestov, a thinker to whom he often alluded and whom he would name as his 'master', who had advanced the view 'that truth lives by contradictions' by posing the provocative question of "whether contradictions are not the condition of truthfulness in one's conception of the world'. ${ }^{13}$

\footnotetext{
${ }^{12}$ Hugh MacDiarmid, Scottish Eccentrics, ed. Alan Riach (Manchester: Carcanet, 1993), 27.. MacDiarmid is quoting from John Willcock's biography of Urquhart, which itself embeds an unattributed quotation. The difficulty here in keeping track of quotation marks is a common one in reading MacDiarmid's criticism.

${ }^{13}$ MacDiarmid, Lucky Poet, 402. Peter McCarey, Hugh MacDiarmid and the Russians (Edinburgh: Scottish Academic Press, 1987), 171.
} 
But there is also a second purpose to the book, a specifically nationalist one, which becomes fully explicit in its concluding chapter. In that essay, 'The Caledonian Antisyzygy', which MacDiarmid had intended to be the introduction, he puts forward a bold argument that the condition of eccentricity is not accidental to his subjects but is rather fundamental to their national makeup, so that in their actions they are doing little more than articulating in exaggerated form the self-contradictions of post-union Scotland. ${ }^{14}$ In this view, " the eccentric actually becomes the typical and the wildest irregularities combine to manifest the essence of our historic function'. ${ }^{15}$ As the essay's title suggests, MacDiarmid is drawing on an argument first articulated by G. Gregory Smith in 1919 and which has become enshrined in Scottish literary and cultural criticism since: that of an essential schizoid Scottish personality divided between extremes of realism and fantasy, canniness and uncanniness, civility and savagery, sacredness and profanity, ${ }^{16}$

Scottish Eccentrics is a profoundly eccentric book in itself, then, but it is a manifestation of an eccentricity with a purpose, an example of what has been described earlier as a strategic eccentricity. In it MacDiarmid is not only making a case for a modernist strategy of cultural and literary estrangement but also showing how this can be tied to an argument about Scottish national culture. Grieve was perhaps never quite manipulative or cool-headed enough to maintain a cynical

${ }^{14}$ See Bold, ed. The Letters of Hugh MacDiarmid, 544-7.

${ }^{15}$ MacDiarmid, Scottish Eccentrics, 286.

${ }^{16}$ See G. Gregory Smith, Scottish Literature: Character and Influence (London: Macmillan, 1919). and, for example, Edward J. Cowan and Douglas Gifford, eds., The Polar Twins (Edinburgh: John Donald,1999). 
distance between himself and the character he had created, and it is arguable that they were more or less identical in temperament and attitude from the start, but for a time in the 1920s and early 1930s it seemed that he was able to deploy MacDiarmid's eccentricities productively in the cause of developing a vital new Scottish poetic and cultural practice. For a while the poetry and the cultural politics seemed, as idiosyncratic and offbeat as they were, to complement and feed off one another.

By the time MacDiarmid came to publish his autobiographical 'self-study' Lucky Poet in 1943, however, that balance appeared to have been lost The eccentricities in that book are as profound as in the earlier work but they are arguably much harsher and less winning. MacDiarmid had undergone a number of severe personal and professional setbacks in the fifteen years before the book appeared, among them job disappointments, marital break-up and family estrangement, problems with alcoholism and sexually transmitted disease, exile in Whalsay, difficulties in seeing eye-to-eye with a number of political parties, literary feuds, and a cultural climate in Scotland that was not always as welcoming to him as he would have liked. A number of these problems had developed before Scottish Eccentrics, but hadn't found expression in that work. In the more confessional mode of Lucky Poet, a work produced, moreover, in the stress of wartime, they are more explicitly present as the sources of a splenetic anger and a defensive arrogance that go far beyond the idiosyncrasies found in the earlier work. Lucky Poet celebrates similar types of refractoriness and self-contradiction as are found in Scottish Eccentrics, with MacDiarmid characterising the book in a later 'author's note' by drawing on what Bold tells us was a favourite quotation from Whitman's 'Song of Myself': 'Do I contradict myself? / Very well then I contradict myself, / (I am large, I contain 
multitudes) ${ }^{17}$ But the sense that this is a productive rather than merely destructive contradiction has arguably disappeared. One reason for this, perhaps, derives from the way MacDiarmid's persona had developed from mere eccentricity, which implies a recognition of decentredness from normative behaviours and values, towards a megalomania which believes itself the rightful centre of normative value.

One of Lucky Poet's epigraphs is from Kierkegaard and states that 'the literary and social and political situation requires an exceptional individual - the question is whether there is anyone in this realm who is fitted for this task except me'. ${ }^{18}$ The extent to which MacDiarmid takes this seriously quickly becomes apparent in the book, which is characterised by a folie de grandeur that can be entertaining and provocative if read as rhetorical hyperbole but more than a little troubling if taken as a statement of fact. Here, for example is MacDiarmid talking of the extent of his erudition and sensitivity:

for twenty years I have read everything about Scotland I could lay my hands on, developing as a consequence a faculty which seems to attract to me instantaneously all the available information on points no matter how obscure or technical from sources no matter how far scattered, and at the same time 'grangerizes' any such issue that is in my mind with a simultaneous

${ }^{17}$ Bold, MacDiarmid, 47. Sculley Bradley et al., eds., Walt Whitman, Leaves of Grass. A Textual Variorum of the Printed Poems, 3 vols., vol. 1: Poems, 1855-1856 (New York: New York University Press,1980), 82, MacDiarmid, Lucky Poet, xi. ${ }^{18}$ Hugh MacDiarmid, Lucky Poet: A Self-Study in Literature and Political Ideals (1943; reprint, Manchester: Carcanet, 1994), vi. 
recollection of all manner of connected (or, no matter how remotely, connectable) matters drawn from the whole field of my tremendous reading, and at once establishes a compenetrant complexity of relationships and ideas for their literary and political utilization. ${ }^{19}$

MacDiarmid had never been, as David Norbrook has put it, a stranger to the 'immodesty topos' but even by his own standards this sounds delusional, as though he really has irrevocably crossed the threshold from difficulty to impossibility. ${ }^{20}$ More immediately alarming is the effect that such attitudes actually have on the literary and political utilizations that MacDiarmid talks of here, and the impact they have on his larger reputation. Lucky Poet helps cement the impression that many commentators have formed of MacDiarmid's exasperating impossibility in these fields.

Politically, MacDiarmid's self-contradictions are well documented, but it important to note the way he effectively marginalised himself from meaningful politics by the kinds of attitude manifested in Lucky Poet. John McCormick, the effective leader of Scottish nationalism in the late 1940s wrote in his The Flag in the Wind that MacDiarmid (Grieve) 'has been politically one of the greatest handicaps with which any nationalist movement could have been burdened', citing 'his love of bitter controversy, his extravagant and self-assertive criticism of the English, and his

\footnotetext{
${ }^{19}$ MacDiarmid, Lucky Poet, 254.

${ }^{20}$ David Norbrook, "What Happened to MacDiarmid," London Review of Books 8, no. 18 (1986): 24.
} 
woolly thinking'. ${ }^{21}$ More recent political commentary has concurred: Colin Kidd arguing, for example, that MacDiarmid's influence has been a particularly malign one and that 'his bequest to Scotland was an uncompromising and Manichean nationalism'. ${ }^{22}$ Grieve had always been a somewhat authoritarian socialist and nationalist, one who argued for the necessity of an elite to guide the intellectual and political development of the masses and had drawn accordingly on models as diverse as V. I. Lenin and the American historian and social theorist James Harvey Robinson. ${ }^{23}$ In Lucky Poet such elitism at times shades into what looks like a more open hostility to his countrymen. In spite of his insistence at various points that it is with a middle class perverted by English values that his quarrel lies, and that the only thing he cares about 'is what the masses of the people think and believe and like and dislike' it is sometimes difficult from the way he hectors and ridicules those masses to distinguish political argument from more straightforward misanthropy and disdain. ${ }^{24}$ 'Modern Scotland is a disease in which almost everything has turned into mud', MacDiarmid writes, and what it 'needs above all else is a stiff dose of [ . . ] well-

${ }^{21}$ It is perhaps wholly typical of MacDiarmid that he quotes McCormick's attack on him at length in his Burns Today and Tomorrow (1959). Hugh MacDiarmid, Albyn: Shorter Books and Monographs, ed. Alan Riach (Manchester: Carcanet, 1996), 276.

${ }^{22}$ Colin Kidd, Union and Unionisms: Political Thought in Scotland, 1500-2000 (Cambridge: Cambridge University Press, 2008), 2-5..

${ }^{23}$ See Scott Lyall, Hugh MacDiarmid's Poetry and Politics of Place: Imagining a Scottish Republic (Edinburgh: Edinburgh University Press, 2006), 163-4.

${ }^{24}$ MacDiarmid, Lucky Poet, 97. 
bred arrogance. ${ }^{25}$ By means of aggressive argument and some semi-farcical mathematics, MacDiarmid asserts that across the English-speaking world there are only five 'reasonably civilized' people for 'each 100, 000 souls'. ${ }^{26}$ The consequence, is that he does not feel bound to the values of the general mass of people who, in this view, have been vitiated by British imperialism and popular culture, but rather stands high above them, heaping murderous contempt on their failures to recognise the eternal truths of art and the leadership qualities of the great artist who moves among them:

There can be no end to war, to mutual mass-extermination, so long as most people remain such morons. Their condition - their attitude to life - is in fact a species of cancer, entirely similar to the way in which cancer cells develop in the body of the host, by the failure of his own tissues to abandon their embryonic form and assume adult status and responsibility. That exactly describes the content of the lives of all but an infinitesimal minority of mankind - that infinitesimal minority, constant through all history, who have built up our entire human heritage of arts and sciences, not only without any help or understanding but in the teeth of extreme indifference and often active opposition from the vast majority who, if that minority were killed out, would speedily lose and be utterly helpless to do anything to replace all the gains of civilization. $^{27}$

\footnotetext{
${ }^{25}$ Ibid., 236.

${ }^{26}$ Ibid., 103.

${ }^{27}$ Ibid., 406-7.
} 
Something that becomes horribly apparent in Lucky Poet, something that had perhaps never been fully formed or expressed so insistently in his earlier writing, is that Hugh MacDiarmid doesn't see himself so much as a fellow sufferer with his fellows in the condition of modernity as a divinely-appointed physician destined to cure them with his draconian surgery. Friedrich Nietzsche said much the same thing in Ecce Homo (1888), a similarly self-aggrandizing work of autobiographical criticism, but Nietzsche was already beginning the slide into clinical insanity by this time and, besides, had left a legacy one part of which MacDiarmid was currently experiencing in the form of a Nazi war: both elements which should perhaps have given MacDiarmid pause in taking him as a model. And while Nietzsche might be excused writing chapters such as 'Why I am so Clever', 'Why I Write Such Excellent Books', and 'Why I am a Destiny' on the grounds of his substantial lifetime recognition and success, MacDiarmid is writing in a context in which for all his bluster of being recognized as the best Scottish poet since Burns he realizes he is 'a sort of Ishmael', an outcast of the nation he seeks to shape, his books unread and his poetry undervalued. ${ }^{28}$ The consequence is that what had seemed like a canny eccentricity or at least an excusable oddity in the character of MacDiarmid, appears in Lucky Poet to harden into something more bitter and potentially, at times, more sinister.

If these attitudes were restricted to the political arena then they might be separable from MacDiarmid the poet and thus be rendered irrelevant to his literary reputation. But Lucky Poet shows the way such attitudes work directly into both the content and the form of the poetry. When he writes verses on Glasgow, for example,

\footnotetext{
${ }^{28}$ Ibid., 234.
} 
MacDiarmid uses similar images of infestation and eradication, pathology and cure, that he employs in his political and cultural discourse, commenting that

I have likened these people in my Glasgow poem to those insects which are repelled rather than attracted if an electric light is substituted for an oldfashioned kerosene lamp, and speculated on consulting Helsmoortel as to what the effect on their mentalities might be if irradiation methods were applied to their genital organs. ${ }^{29}$

And again, when he talks of his ideals for poetry - of the type of poetry he has been working on in wartime and will go on to publish in the likes of In Memoriam James Joyce (1955) and The Battle Continues (1957) - a similar emphasis seems to haunt both its form and its subject matter. MacDiarmid talks of having a

dream of creating a poetry which will operate on mankind as one obituarist of James Joyce said of Joyce's novels - that 'even the strongest of his characters seems dwarfed by the great apparatus of learning that he brings to bear on them. They are almost like atoms being smashed in a 250-ton cyclotron.' This, indeed, is what I would like to see people, not characters in books but all their readers, subjected to; I dream of a literary equipment which may bring immense erudition to bear on the general unsanity of mankind, on the appalling mindlessness of almost everybody, like the insulin and metrazol 'shock' treatments of Dr. Lother Kalinowsky's later utilization of electricity, for dementia praecox. ${ }^{30}$

\footnotetext{
${ }^{29}$ Ibid., 105.

${ }^{30}$ Ibid., 407-8.
} 
This is, in its quasi-scientific language and its insistence on deploying vast amounts of knowledge as a kind of blunt clinical instrument to effect violent behavioural change in its subjects, an effective if rather chilling outline of the mode of much of MacDiarmid's later poetry.

MacDiarmid was perfectly capable of producing great poetry that was at variance with his critical and political ideas as well as his personal circumstances, as a poem such as 'On a Raised Beach', written during the harshest years of his Shetland exile, shows. But it is arguable that as the ideas expressed in Lucky Poet take hold of his poetry the less rewarding it becomes, and the less he can break free of them to create a poetry like that exemplified in 'The Terrible Crystal' that is capable of 'fusing the discordant qualities of experience, / Of mixing moods, and holding together opposites'. ${ }^{31}$ His work instead tends increasingly toward discordance without fusion, towards intemperance and an inordinate, sometimes incoherent, prolixity - work, in other words, that grows and grows in the warmth of its author's sense of his infallibility to the point where it leaves simply no room for the common reader. In The Company I've Kept (1966) MacDiarmid would suggest that the reason his poetry had developed in the way it had was precisely because of his need to make it affront the expectation and baffle the comprehension of what he described as the 'bastard democracy'. In this view the massive sprawl of his writing and the hyperinflation of his persona, summed up in his call 'for GIANTISM in the arts', are part of

\footnotetext{
${ }^{31}$ Hugh MacDiarmid, Complete Poems, ed. Michael Grieve and W. R. Aitken, 2 vols., vol. 2 (Manchester: Carcanet, 1994), 1095 .
} 
his master plan for an 'expansion of creative genius to a point where all the little people simply can't comprehend it and are excluded automatically, ${ }^{32}$

None of this can, on its own, entirely destabilise the poetry. By allowing his persona to swell to a size that made his political and cultural pronouncements absurd and sometimes monstrous, MacDiarmid could never extinguish the technical skill and the flashes of insight and beauty that mark his best poetry. But he certainly made them much harder to find, and made even critics who wanted to praise him feel they had to qualify their remarks to account for his excesses. C. H. Sisson was one: a poet and critic who valued MacDiarmid as an inspiration to his own development but who remained troubled by MacDiarmid's poetic and personal indiscipline:

For the oeuvre is a vast, untidy, often cantankerous affair and the author not just a man who wrote poems but an off-beat politician of the most injudicious kind, occasionally violent in language and apparently unable to resist the pleasure of making small noisy impacts on a world he had neither the patience nor the practical sense - nor perhaps really the will - to act on more effectively. $^{33}$

Seamus Heaney is another admirer who acknowledges that 'anyone who wishes to praise his work has to admit straightaway that there is an un-get-roundable connection between the prodigality of his gifts and the prodigiousness of his blather.' For Heaney, 'the task for everybody confronted with the immense bulk of his collected

\footnotetext{
${ }^{32}$ Hugh MacDiarmid, The Company I've Kept (London: Hutchinson, 1966), 56.

${ }^{33}$ C. H. Sisson, “MacDiarmid's Sticks,” London Review of Books 6, no. 6 (1984): 16.
} 
verse is to make a firm distinction between the true poetry and what we might call the habitual printout.' This however, is a distinction Heaney is prepared to work on and he finds especially in the early work in Scots enough to justify MacDiarmid's status as a significant poet, even though he admits that MacDiarmid's later poetry, with its 'skewed rhythms, egregious diction, encyclopedic quotation, sheer monotony [ ... ] certainly gave his detractors plenty to work with' ${ }^{34}$

Richard Aldington noted something very like this quality in criticism of D. H. Lawrence (1885-1930): the sense that praise of Lawrence never came unqualified and that any ascription of literary genius to him was always followed by a 'but' ${ }^{35}$ It is arguable whether the work of MacDiarmid and Lawrence can really be fruitfully compared but in this regard at least it is against Lawrence and the likes of Ezra Pound that he should be measured. Like them he is an eccentric, a member of the awkward squad, a Modernist gadfly: valuable for his boldness in confronting convention and capable of some very fine writing, but the practitioner of an aesthetic so contentiously singular and ego-driven that it can never be fully subscribed to nor productively followed. The reasons why no-one would really think seriously about placing Lawrence at the centre of the English literary tradition or Pound the American tradition are exactly those that make it difficult to give MacDiarmid the place he felt was his at the centre of a revivified Scottish tradition. Pound and Lawrence were both in their own ways 'impossible people' in the terms MacDiarmid had characterized

\footnotetext{
${ }^{34}$ Seamus Heaney, " A Torchlight Procession of One," Parnassus: 21, no. 1/2 (1996): $11-29$.

${ }^{35}$ Richard Aldington, Portrait of a Genius, But . . The Life of D. H. Lawrence 18851930 (London: William Heinemann, 1950).
} 
himself to Gunn, but they lacked MacDiarmid's sense of a larger commitment to nation. The concerns of both were eccentric to their countrymen, but the loss of that common centre appeared to cause them few qualms. Their impossible personae were consistent with their status as exiles and their rightist politics.

The consequences of MacDiarmid's eccentricity were quite different. How could a figure who had strategically embraced 'impossibility', self-centredness, and volatility as the constituent elements of his public persona occupy the centre of a culture and speak with the normative voice that is demanded by the discourses of democratic leftism and nationalism, what he called 'that particular Scottish democratic spirit', which he ostensibly - if, as we have seen, only rather intermittently - espoused $?^{36}$ Instead, we find an individual who in Lucky Poet states it 'part of my job to keep up perpetually a sort of Berserker rage' and who would later describe his role as being 'to erupt like a volcano, emitting not only flame but a lot of rubbish' ${ }^{37}$ MacDiarmid was being unduly hard on himself here, and perhaps even being a little wry, yet there is something arresting and appropriate in these images. A volcano is a visible manifestation of tectonic activity, of the kind of immense seismic pressure that forges new continents and makes diamonds from organic detritus. It is magnificent and elemental, but it is also a nuisance and a threat to the people who try to make their daily living in its shadow. A berserker, too, is impressively elemental but a figure who one might not be inclined to invite into one's home, whether in the pages of a book or not.

\footnotetext{
${ }^{36}$ MacDiarmid, Lucky Poet, 207.

${ }^{37}$ Ibid., 79. Letter to George Bruce, 1 July 1964, Bold, ed. The Letters of Hugh MacDiarmid, 531.
} 
MacDiarmid's attempt to make himself a remorselessly inhuman figure in his criticism and later poetry, to be as Ian Crichton Smith put it, a 'cold eagle, a man in love with stones', might be seen as an impressive assault on the values of what MacDiarmid saw as 'the emptiness and insignificance of sentimental humanism, ${ }^{38}$ But it perhaps came at a personal cost. There is much evidence, especially in his later life, that Christopher Grieve was a very different, much kinder man than Hugh MacDiarmid: a generous mentor to young poets and a man keen to build the bridges with family and friends that he had earlier burned in the fires of his MacDiarmidesque mania. The sense in which there was a more vulnerable person lurking behind MacDiarmid had not been lost on Valda Trevlyn, Grieve's second wife, even from the beginning of their relationship. She would tell Alan Bold after Grieve's death of a different, more gentle kind of eccentricity to which she was attracted in his character and which proved decisive in committing herself to him:

I didn't really believe in the business of 'Hugh MacDiarmid' or any of that: this business of being a Scottish poet was all baloney. What really decided me was when I was standing in the Tottenham Court Road. Christopher had gone down to the lavatory and had gone into the women's. I thought, 'Oh, my God, I can't leave him.' A silly way to decide anything. ${ }^{39}$

Had MacDiarmid opened himself up a little more to the very human fallibility present here, been more alert and sympathetic to the frailties and vulnerabilities not only of

${ }^{38}$ Ian Crichton Smith, "The Golden Lyric: The Poetry of Hugh MacDiarmid, in Towards the Human: Selected Essays (Edinburgh: MacDonald, 1986), 185. MacDiarmid, Lucky Poet, 78.

${ }^{39}$ Bold, MacDiarmid, 303. 
others but of himself, he might have become a more rounded, less remorselessly fractious figure and would almost certainly have enjoyed a more settled life. He might have felt less temptation to use his poetry as a bludgeon rather than a foil, and as a consequence have required less of the special pleading that those who value his work often feel they need to apply in its defence. If he really wanted to be the saviour of his national culture he might have tried a little harder to get his readers to nod their heads rather than scratch them. Hugh MacDiarmid had only himself to blame for being an impossible person but C. M. Grieve should, perhaps, have known a little better. 